\title{
Imagining the anti-gang: the state, the father and Jean-Claude Van Damme
}

\author{
Maarten Hendriks
}

Abstract: Empirically focusing on the so-called anti-gang, a civilian policing group in the city of Goma (DRC), this article examines the nexus between the workings of the imagination and the politics of everyday policing. Four forms of political imaginations through which the anti-gang imagine themselves as everyday policing actors are identified: political imaginations around the state, citizenship, the father, and martial arts and action movies. The article makes two main arguments. First, political imaginations are not merely fantasies. Instead, the anti-gang harness them to do political work and impose themselves as street authorities. In doing so, they in turn contribute to giving form to these political imaginations, by making them tangible and experienced as real in everyday urban life. Second, the article asserts that the political imaginations that shape and are shaped by anti-gang practices show that they do not so much propose a new political order. Instead, they seek to be included in it, escape marginalisation and become politically significant.

Keywords: Civilian policing group, everyday policing, political imagination, Goma, DRC.

Note on the author: Maarten Hendriks is a postdoctoral researcher (BOF scholarship) at the Conflict Research Group (CRG), department of conflict and development, at Ghent University. His research interests are focused around youth, violence, gangs, vigilante-type organisations and visual epistemologies. Publications include: (2018), 'The Politics of Everyday Policing in Goma: The Case of the AntiGang', Journal of Eastern African Studies, https://doi.org/10.1080/17531055.2018.1459976; (2019), “"Мy Life Is Like a Movie": Making a Fiction Film as a Route to Knowledge Production on Gang Political Performances in Goma, DR Congo', Journal of Extreme Anthropology, https://doi.org/10.5617/jea.6695.

Maarten.Hendriks@Ugent.be

(C) The author(s) 2021. This is an open access article licensed under a

Creative Commons Attribution-NonCommercial-NoDerivs 4.0 Unported License 


\section{Introduction}

In a rapidly urbanising global context, ${ }^{1}$ urban (in)security presents a key challenge for societies worldwide. Broader than matters of (in)security, as Beall et al. (2013) assert, violent conflict has become increasingly urban, to the extent, as these authors argue in dialogue with Wolf's classical analyses on the 'peasant wars of the 20th century' (Wolf 1999), that we have entered the era of 'urban wars of the 21st century' (Beall et al. 2013: 3066). This is no less true for African societies and cities (see for example Büscher 2018). However, for eastern Congo - the regional focus of this article-as Verweijen notes: 'The standard imagery of violence ... is that of armed groups clashing in rural zones, conducting raids on villages and raping women' (Verweijen 2019: 11). In the shadow of soldiers and rebels fighting each other in the rural hinterlands, conflict studies have long overlooked dynamics of 'urban' insecurity and violent conflict in eastern Congo (with some noteworthy exceptions ${ }^{2}$ ). Empirically focusing on the so-called anti-gang, a civilian policing group in Goma, this article aims to contribute to bridging this knowledge gap. It does so by examining the nexus between the politics of everyday policing and the workings of the imagination.

The anti-gang are socio-economically marginalised youths from Goma's popular neighbourhoods ${ }^{3}$ that see it as their core mission to protect the inhabitants of Goma against everyday crime and violence committed by the maibobo (street kids). They operate in popular neighbourhoods on the 'urban margins' (Goldstein 2012), characterised by higher levels of physical and livelihood insecurity compared to Goma's wealthier city centre (Kyed 2018). Whilst an impressive police and military force is deployed in Goma, the police stations in Goma's outskirt popular neighbourhoods are largely understaffed. ${ }^{4}$

In return for their offer of protection to the urban inhabitants, they hold weekly collections of $200 \mathrm{FC}(0.20 €)$ per shop and vendor in their 'territory'. Besides, they carry out small jobs for the police, the intelligence services and the municipal authorities, such as evicting pirate markets, searching for wanted criminals and assisting in knocking down protests. In short, the anti-gang are a clear example of how urban insecurity and violent conflict, as Büscher argues, 'not only puts cities under pressure,

\footnotetext{
${ }^{1}$ Whilst today around 54 per cent of the global population lives in cities, the UN has estimated that this amount will grow to 66 per cent by 2050 (Mitton 2018).

${ }^{2}$ See for example: Thill (2019); Verweijen (2019); Muzalia (forthcoming); Büscher (2011); Pole Institute (2009).

3 The term popular neighbourhoods (quartier populaires) refers to those city neighbourhoods outside Goma's wealthier city centre: the former colonial cité Européenne (European quarter).

${ }^{4}$ For more detail, consult the report 'Insecurity in Goma: Experiences, Actors and Responses' (Hendriks M. \& Büscher 2019).
} 
it also creates openings, opportunities and capabilities for new urban constellations to unfold' (Büscher 2018: 4).

Drawing upon Kyed's concept of 'street authority', this article investigates the distinct style of politics and authority that is produced by civilian policing groups, such as the anti-gang, in their own right; 'a style of politics that intertwines with but also significantly differs from official competitive politics and state sovereignty' (Kyed 2018: 31). As Mbembe (2001: 76) notes on what he conceptualises as forms of privatisation of lawful violence: 'such phenomenon are not automatically indicators of chaos. It is important to see in them, also, struggles aimed at establishing new forms of legitimate domination and gradually restructuring formulas of authority built on other foundations'. This begs the following questions: what are these other foundations? How do organisations like the anti-gang seek to restructure formulas of authority? And what kind of political order do they envision?

To elaborate on these questions this article analyses how the anti-gang in Goma imagine their role as everyday policing actors themselves. How does the work of the imagination enable political action by which anti-gangs (seek to) impose themselves as street authorities? And how do anti-gang practices of everyday policing feed into and are shaped by political imaginations of order-making and authority?

Conceptually, this article draws from Rivke Jaffe's (2018) understanding of the 'political imagination'. Beyond emphasising that the imagination is political, her conceptualisation of political imagination refers 'to a particular realm of the imagination: to imaginings of political order, of how power works and how it should work' (Jaffe 2018: 1099). Political imaginations guide how we understand the workings of power, and legitimise or delegitimise how power, authority and resources are distributed. As Jaffe (2018: 100) notes: 'the political imagination is central in how we come to see ourselves in relation to others: with whom do we feel affinity or community, what forms of authority and hierarchy do we find acceptable?

In the article, I identify four forms of political imagination that inspire the antigang in taking up their role as everyday policing actors: political imaginations around (i) the state, (ii) citizenship, (iii) the father, and (iv) martial arts and action movies.

The article makes two main arguments. First, political imaginations are not merely fantasies, but are harnessed by the anti-gang to do political work and impose themselves as street authorities. To be experienced as real, Meyer argues, 'imaginations need to materialise in the concrete lived environment and be felt in the bones' (2009b: 5). This is precisely the work of the imagination that the anti-gang are engaged in. By harnessing political imaginations around the state, the father, citizenship and the global imagery of martial arts and action movies, these imaginations 'touch ground and yield tangible forms and formations in social life' (Meyer 2009b: 3). In short, anti-gang practices are both informed by and give form to political imaginations of order-making and authority. As Jaffe (2018: 1101) emphasises: 'these relations are not 
causal in any unidirectional sense, ... the imagination is not so much a concrete causative object or subject, but rather an ongoing process'.

Second, after situating the anti-gang as street authorities and the analyses of each identified form of the political imagination, I conclude that the anti-gang do not propose a fundamentally new socio-political order. They seek to be included in it, escape marginalisation and become politically significant by inscribing themselves into-and thus reinforcing - dominant and powerful political imaginations of order-making.

Methodologically, the article draws upon 16 months of ethnographic fieldwork on gangs and anti-gangs in Goma between 2015 and 2019. Moreover, it builds upon visual materials I produced and gathered in the field. First, my research collaborators ${ }^{5}$ and I handed out cameras and smartphones to leaders from different anti-gang groups in the city. We asked them to film and photograph everything they found meaningful about their lifeworld, especially when we were not with them. These photos and film fragments were regularly discussed during field visits. Second, in collaboration with TD Jack Muhindo (a Congolese cineaste) we produced two action movies - of which one (Monstre's Prison Break) will be discussed in this article.

A previous article elaborates on how I developed this filmmaking method, and its epistemological principles (Hendriks M. 2019). In short, on their demand, we facilitated their making of their own movie about their lives as gangs and anti-gangs, re-enacting their roles and experiences as everyday policing actors. What makes these films ethnographically exciting is that they are 'reflexive exercises' (Turner 1982) of (anti-) gangs representing (and imagining) themselves and their lifeworld the way they see fit. For the purpose of this article, the film Monstre's Prison Break serves as an analytical tool to investigate how they imagine themselves as gangs and anti-gangs through martial arts and action movies.

\section{The anti-gang as street authorities}

Since the early 1990s, Congo's eastern provinces have been caught up in a deadly protracted armed conflict. Whilst the actual war-violence mainly takes place in eastern Congo's rural hinterlands, levels of urban crime and violence have also increased dramatically in the past two decades. The ways in which urban violence and broader conflict dynamics are interlinked are a complex matter (see Verweijen 2019; Thill 2019; Hendriks M. \& Büscher 2019). For Goma, the provincial capital of North Kivu at the Congo-Rwanda border, Karen Büscher (2011; 2016) demonstrates that, overall, the city became a zone of refuge and relative safety at the heart of the conflict. It became a humanitarian hub hosting the MONUSCO (until recently the largest UN

${ }^{5}$ Christian Irenge, Rosette Watanga and TD Jack Muhindo. 
peacekeeping mission in the world) and numerous national and international NGOs; opened up opportunities for business; and attracted large numbers of refugees and IDPs fleeing the violence in the neighbouring country of Rwanda during and after the 1994 genocide and eastern Congo's war-affected areas in the Kivus. The rapid and largely uncontrolled expansion and urbanisation that followed placed strain on urban social infrastructures, creating a context for urban violence and (in)security levels to increase (Büscher 2011; Büscher \& Vlassenroot 2010).

Youths position themselves amongst the leading actors of both rural and urban crime and violence: fighting in the regular army or armed groups, roaming the streets as maibobo (street children) trying to get by, or being active in urban street gangs. In a wider context of social exclusion, economic decay and a general cultural experience of what Mbembe (2002) conceptualised as 'the state of war', violence in the Kivus became one of the few opportunities for many youths to escape social marginalisation. ' $[\mathrm{M}]$ any youngsters are looking for a new identity and violence furnishes them alternative modes of identification and an opportunity to impose their own subjectivity' (Jourdan 2004: 157).

From their side, the anti-gang also partake in this youthful political economy of violence. In short, they are sportifs (martial arts practitioners) and gangs, ${ }^{6}$ which transform themselves into anti-gangs, claiming to protect Goma's inhabitants against the everyday urban crime and violence of the maibobo and other gangs. They were founded at the Virunga market (Goma's principal market) in 2007 to stand guard at the market and protect market traders and their customers from theft and other harassments. With the support of Roger Rachidi Tumbula, Goma's mayor between 2008 and 2010, the anti-gang gradually expanded their activities throughout Goma's popular neighbourhoods (see Hendriks M. 2018). Since 2010, anti-gang operations have been constantly in flux. On my last field visit in March 2019, after a series of conflicts with certain high-ranked $\mathrm{PNC}^{7}$ officers, the anti-gang member were forced to go into camouflage, as they say; meaning they could not operate in the open and performed their practices of policing and protection rackets in a more hidden fashion. For how long they will be forced into hiding is a question that remains open for now. It is clear, however, that since 2008, with up and downs, the anti-gang in certain popular neighbourhoods managed - to some extent - to take control of the streets.

${ }^{6}$ Throughout the article the word gang is put in italics, referring to the emic understanding of how it is used in Goma. Rather than denoting a group of people involved in illicit behaviour, it refers to a person that has gang qualities; centred around toughness in both a negative and positive sense. Gangs are the marginalised but tough 'kids from the neighbourhood' who know how to make a living on the streets. Together with the maibobo, they are often blamed for much of the everyday urban crime happening in Goma (see also Hendriks M. 2018; 2019).

7 Police National de Congo - The National Congolese Police. 
The following observation illustrates how the anti-gang imposed themselves as authorities 'in their own right' (Kyed 2018):

Arriving with my research collaborator in the neighbourhood of Ndosho, we saw a crowd gathered in front of a shop not far from Station Simba. Five anti-gangs blocked the entrance with their arms crossed and nunchuks around their necks; protecting the shopkeeper from being arrested by two police officers for buying (fencing) a motorcycle engine stolen from a private security company. The anti-gang asked the police officers for the document that authorizes them to arrest the shopkeeper. 'They did not have it, so we refused' said one anti-gang. 'We protect the population. We cannot accept them to arrest this man without documents'. When the police officer in uniform tried to get to the shopkeeper, an anti-gang blocked his way. He took the machine gun of the police officer and threw it on the ground; provoking him by saying: 'take your weapon'. People around the shop applauded and laughed. Smelling danger, the police officer apologized and quickly reached for his gun. Some minutes later, the police officers walked away empty handed, to come back the day after with a convocation letter for the shopkeeper which they handed over to the anti-gang leader. ${ }^{8}$

These and other observations show that the anti-gang should be understood as what Kyed has conceptualised as street authorities, referring to the 'pervasive yet ambiguous' style of authority civilian policing groups produce on the urban margins (Kyed 2018: 31). Characteristic of this style of authority is momentariness: 'the capacity to act swiftly without hesitation and without being bound-up to strict rules and codes of conduct' (Kyed 2018: 20). Whilst their ability to bring quick results in terms of policing and order-making makes them attractive for both people in the neighbourhood and official authorities for collaboration - to find stolen goods, beat up and deter maibobo, knock down protests and so on - at the same time it makes their authority morally ambiguous. Complaints are often made that the anti-gang are themselves involved in crime and collaborate with thieves and maibobo. Multiple residents referred to the anti-gang as 'maibobo that have grown up', ${ }^{9}$ or as one resident put it: 'a microbe that kills another microbe'. ${ }^{10}$ Their ambiguous and momentary character, in turn, renders their authority rather unstable (Kyed 2015; 2018). Whilst the anti-gang can get things done, at the same time they are seen as a nuisance by both the state authorities and Goma's inhabitants. The above observation shows that whilst they are at times instrumentalised by state authorities, they are also (street) authorities in their own right. This article seeks to elaborate on Kyed's concept of 'street authority' by examining the imaginary foundations that underlie such authority.

\footnotetext{
${ }^{8}$ Observation, Ndosho, Goma, 8 December 2015.

9 Informal conversation with resident, Goma, 13 April 2016.

${ }^{10}$ Informal conversation with bus-driver, Goma, 12 November 2015.
} 


\section{Stateness and citizenship}

The following video ${ }^{11}$ (scan the QR code on the right) shows how an anti-gang group hands over apprehended thieves to the police. On the uniform of the anti-gang in the picture is written sécurité civile, Maire de Goma (civilian security, city hall of Goma), referring to both 'citizenness' and 'stateness' (Hansen \& Stepputat 2001; Hoffmann et al. 2016). This section elaborates on this apparent paradox, dealing with how the anti-gang, to impose themselves as street authorities, simultaneously harnesses prevalent political imaginations around stateness and citizenship. In explaining what drives and motivates them in their mission, two anti-gang leaders responded:

The police, the military and the ANR [National Intelligence Agency] don't do a good job. They are not from here, so they do not know the environment. What is more, they collaborate with bandits. We on the other hand are Gomatraciens. We know everything and everyone here. ${ }^{12}$

It is not the money. We do what we do in the framework of auto-prise en charge [fending for oneself]. We live here. We are watoto ya Goma [children of Goma]. Our family and friends live around this market. They are in insecurity! The police are not effective and are not from here. ${ }^{13}$

These quotes show that in legitimising themselves, anti-gang members clearly differentiate themselves from the state police (PNC), military $\left(\right.$ FARDC $\left.^{14}\right)$ and intelligence services $\left(\mathrm{ANR}^{15}\right)$. As one anti-gang bluntly asserted: 'we are there because they fail'. ${ }^{16}$ Hereby they tap into the general feeling of dissatisfaction amongst Goma's inhabitants with the state security services; blaming them for being ineffective in combatting - and even complicit in - urban crime.

Furthermore, the above citations exemplify how they deploy imaginations around citizenship. First, they stress that they are Gomatraciens or watoto ya Goma (children of Goma). They need to protect their home where their friends and family members live. By contrast, the PNC and FARDC are deployed according to a military logic, which means they frequently rotate to other parts of the country to not familiarise themselves too much with the people they are policing. As I explained elsewhere (Hendriks M. 2018), political imaginations around being Gomatracien can be seen as a cosmopolitan variant of autochthony or 'sons of the soil'. According to this logic, the original inhabitants 'are regarded as the rightful owners who can ultimately decide how their territory is governed, whereas members of other ethnic groups which "do

11 Video fragment filmed by anti-gang leader, Goma, 3 November 2015.

12 Informal conversation with two anti-gang leaders, Goma, 27 October 2015.

13 Informal conversation with two anti-gang leaders, Goma, 27 October 2015.

${ }^{14}$ Forces Armées de la République Démocratique de Congo - the Armed Forces of the Democratic Republic of Congo.

15 Agence National de Renseignements - National Intelligence Agency.

${ }^{16}$ Informal conversation with anti-gang, Goma, 13 June 2017. 
not belong" to that area are given the status of settlers who have to accept the hegemony of the "sons of the soil"" (Harnischfeger 2010: 55). In the cosmopolitan urban environment of Goma, a variety of ethnic groups are present and many originate from elsewhere. As Büscher (2011: 171) notes for Goma, "urban citizenship is more than a matter of "origins", it has also to do with a lived sense of belonging'. However, in a similar sense, people who grew up or lived in the city for a long enough time also identify with being its 'sons' or children (Hendriks M. 2018). Thus, an important difference with the more exclusionary logic of being 'sons of the soil' is that the cosmopolitan variant of 'being a Gomatracien' can be much more easily acquired.

Hence, by emphasising being Gomatracien, the anti-gang claim their 'right' to be involved in the governance of urban security. It shows how in legitimising themselves, the anti-gang both draw from and give shape to the notion of Gomatracien as a powerful urban political imagination of belonging. They feed into this political imagination in a gang-like fashion. Whilst they are gangs they are also 'children of Goma', and thus responsible for its protection. As gangs, they can use their inside knowledge about Goma's gang world to become responsible citizens or Gomatraciens. ${ }^{17}$

Second, they insist they take on their role as anti-gang in the framework of autoprise en charge (taking care of oneself). In the economically declining Zaire of the 1980s, President Mobutu installed the notorious imagined article 15 of the constitution, which states: débrouillez-vous (fend for yourselves). As Jourdan notes:

The 'article 15' can be considered as an implicit social pact between the state and its citizens since it allowed the former to retire from public life and from its functions, leaving to the latter the possibility to act unlawfully, in a context where the difference between legality and illegality had no more sense and everything was left to the capability of individuals to cut out a personal space of power within the society (Jourdan 2004: 170).

Within this context citizens were also encouraged to 'fend for themselves' in terms of public service provision and take over services that were previously provided by the state, such as security provision. This 'fend for yourself attitude' is referred to as l'auto-prise en charge de la population (Carayannis et al. 2018: 23; Verweijen 2016; Thill \& Cimanuka 2019). Although President Mobutu is dead, l'auto-prise en charge remains alive and kicking in Congo today as a political imagination through which peopleincluding the anti-gang - partake in and legitimise political action in terms of 'public service provision', such as taking measures in protecting oneself from crime. The implicit social pact of article 15 is also still frequently called upon to justify predatory behaviour and 'self-interested opportunism in all spheres of life' (Carayannis et al. 2018: 23; Jourdan 2004).

${ }_{17}$ This 'becoming responsible citizens' is further elaborated upon in the following section. 
Although the anti-gang clearly differentiate themselves from the state security services, by harnessing citizenship political imaginations around being Gomatracien and auto-prise en charge, at the same time, they are careful not to frame themselves as antistate. They aim to be considered as an 'additional mode of policing' (Grätz 2010: 81). To avoid conflicts with the PNC — which do arise ${ }^{18}$ - they are vigilant not to give the impression that they seek to compete or replace the PNC or take over its functions. As one anti-gang put it: 'we are the eyes of the police, not its competition'. ${ }^{19}$

We are not against the government, we are against thieves. We are the people. We have our children, parents, sisters, everyone here. We complement the police. The police cannot be everywhere. $^{20}$

In sum, the anti-gangs insist that they are different from the ineffective and corrupt state security services without portraying 'a revolutionary or anti-state message' (Gore $\&$ Pratten 2003: 232). At the same time, they seek to be inserted into state networks, to 'complement' and carry out jobs for them in return for patronage and protection (Hendriks M. 2018). The following video (scan the QR code on the left) — shot by an anti-gang leader ${ }^{21}$-illustrates this; it shows an operation carried out for the municipal authorities where the anti-gang evict a so-called pirate market, ${ }^{22}$ accompanied by an ANR agent (an intelligence officer wearing civilian clothes). Dressed up in brown uniforms, they coerce people to 'tosha soko ku barabara' (remove the market from the streets), hurling trade goods on the ground of those who do not respond quick enough. The video fragment and the fact that they seek to be inserted in state networks clearly shows that they do not operate in a security vacuum left by an 'absent or failed state'. On the contrary, anti-gang practices are articulated within wider struggles for authority within Goma's socio-political arena (Hendriks M. 2018). The above video fragment also demonstrates that, although they claim that they are not the state, they are engaged in 'state-like performances' (Kyed \& Albrecht 2015; Kirsch \& Grätz 2010b). During the operation where they evict the pirate market, they look, shout and act like the police and military. Hereby they enact what Hansen \& Stepputat (2001) have conceptualised as 'languages of stateness' - enacting practices (of policing) and drawing from symbolic registers of authority associated with the state (Hoffmann et al. 2016). Making a similar observation on Mai-Mai (armed) groups in the Kivus, Hoffmann \& Verweijen (2019: 16) assert:

\footnotetext{
18 See Hendriks M. (2018) for more detail.

19 Informal conversation with Patient, 31 March 2016.

${ }^{20}$ Informal conversation with anti-gang, 21 January 2016.

${ }^{21}$ Video fragment of the eviction of a pirate market shot by an anti-gang leader, Goma, 1 November 2015.

${ }^{22}$ These are markets, often alongside the road, that do not have the official authorisation of the municipal authorities.
} 
Despite widespread discontent with state authorities, languages of stateness remain firmly implanted in Congolese citizens' understandings of political order. Stateness evokes a particular discourse of power, which is associated with officiality, bureaucracy, sovereignty, bounded territory, the law, and what it means to be Congolese in terms of citizens' rights and obligations vis-à-vis the state and the nation.

Clearly, anti-gang practices of policing are informed by this broadly shared understanding, or political imagination, of the state as an organising principle of society. ${ }^{23}$ As described earlier for the citizen imaginations of auto-prise en charge and being Gomatracien, the anti-gang invoke the state imaginary to legitimise themselves as street authorities; to enable the political work of everyday policing. In turn, anti-gang practices also give shape to this state imaginary, which can hardly be called a figment of the mind. Through wearing state-like uniforms, operating in collaboration with state security agents (such as the ANR agent or PNC officers in the video fragments above), and acting police- and military-like, this dominant imaginary of the state 'touches ground' (Meyer 2009a: 3) and becomes very tangible in everyday urban life.

The point of interest here is not to determine whether civilian policing groups such as the anti-gang are 'state' or 'non-state', or to place a normative judgement on Congolese state agencies in Goma as 'failed' [compared to what?] or 'absent' [they are not]. By enacting and harnessing the state imaginary, civilian policing groups such as the anti-gang illustrate that the state-society boundary is porous and elusive (Kirsch \& Grätz 2010b; Mitchell 1991). At the same time, it shows, as Mitchell asserts, that 'producing and maintaining the distinction between state and society is itself a mechanism that generates resources of power' (Mitchell 1991: 90).

In sum, anti-gang practices are informed by and give form to simultaneously political imaginations of stateness and citizenship. Although they claim to be its opposite, at the same time they subject themselves to the imaginary of the state as ruling over society. In this regard, as Lund (2006: 689) argues for what he conceptualises as 'twilight institutions', 'the idea [or imaginary] of the state is also effectively propelled by institutions which challenge the state but depend on the idea to do so'. In terms of state-society relations, the anti-gang do not imagine a fundamentally new political order. They feed into, rather than reinvent, dominant political imaginations around stateness and citizenship. However, in their claims to authority, the anti-gang do more than merely imagining themselves along the lines of stateness and citizenship. In the following sections I elaborate how their practices of everyday policing are also shaped by, and shape forms of, political imagination around the father and martial arts and action movies.

${ }^{23}$ This is not particular to Congo, but is noted for a variety of cases worldwide (see for example Pratten \& Sen 2007; Kirsch \& Grätz 2010a; Feltran 2020). 


\section{The father}

Another form of political imagination the anti-gang deploy in imposing themselves as street authorities relates to the figure of the father. In Schatberg's well known Political Legitimacy in Middle Africa (2001), he argues that 'political legitimacy in this corner of the globe rests on the tacit normative idea that government stands in the same relationship to its citizens that a father does to his children' (Schatzberg 2001: 1). For Congo, the most illustrative example is ex-president Mobutu, who liked to present himself as the father of the nation. According to this paternal logic, a bon père de la famille (a good father of the family) loves and nurtures his children, but on the flipside also disciplines and punishes them when behaving badly. Schatzberg notes that these paternal and familial metaphors did not restrict themelves to references to the president. '[T]here was also a replication of this imagery and metaphor at other levels throughout the state machinery and in other segments of society' (Schatzberg 2001: 2).

It is important to note that politics infused with the political imagination of the father - nurturing and disciplining its children — did not start with the long reign of Mobutu, nor can be put aside as a pre-colonial 'African' way of understanding politics. To a large extent, as de Sardan (2008) notes, it needs to be traced back to colonisation. Like elsewhere in Africa, the Belgian coloniser expressed their relationship with the 'natives' in 'stark terms of father and child' (Gondola 2016: 42); i.e. in need of being 'civilised', educated and punished when necessary.

In Goma's gang world, the political imagination of the father is embodied in the personage of the maître (master), a patron amongst gangs, who guides and takes care of (encadre) his petits (little ones, inferiors). It is a social status that is given to the fiercest, strongest and most streetwise amongst gangs. As further elaborated upon in the following section, high importance is given to mastering martial arts. Within the antigang, maîtres are often black belts in Shotokan or judo. Others are qualified boxers and weightlifters. ${ }^{24}$ There are multiple maîtres in the anti-gang who are hierarchically structured. Overall, each neighbourhood group has one or two maittres who often fill the position of chef d'axe ${ }^{25}$ (group leader) and chef de patrouille (patrol leader). ${ }^{26}$ As

\footnotetext{
${ }^{24}$ Weightlifters were looked down upon by other maîtres in the martial arts who did not see weightlifting as a martial art.

${ }^{25}$ They use 'axe' to demarcate their territory of one anti-gang group.

${ }^{26}$ Furthermore, for most of my fieldwork - until he was set aside because of internal struggles over leadership - the different groups were overseen by the coordinator and founder of the anti-gang, maître Robin (this name is anonymised), the maître of all anti-gangs. After Maître Robin was set aside, multiple neighbourhoods had their own independent groups of anti-gangs who did not respond to one overall leader/coordinator.
} 


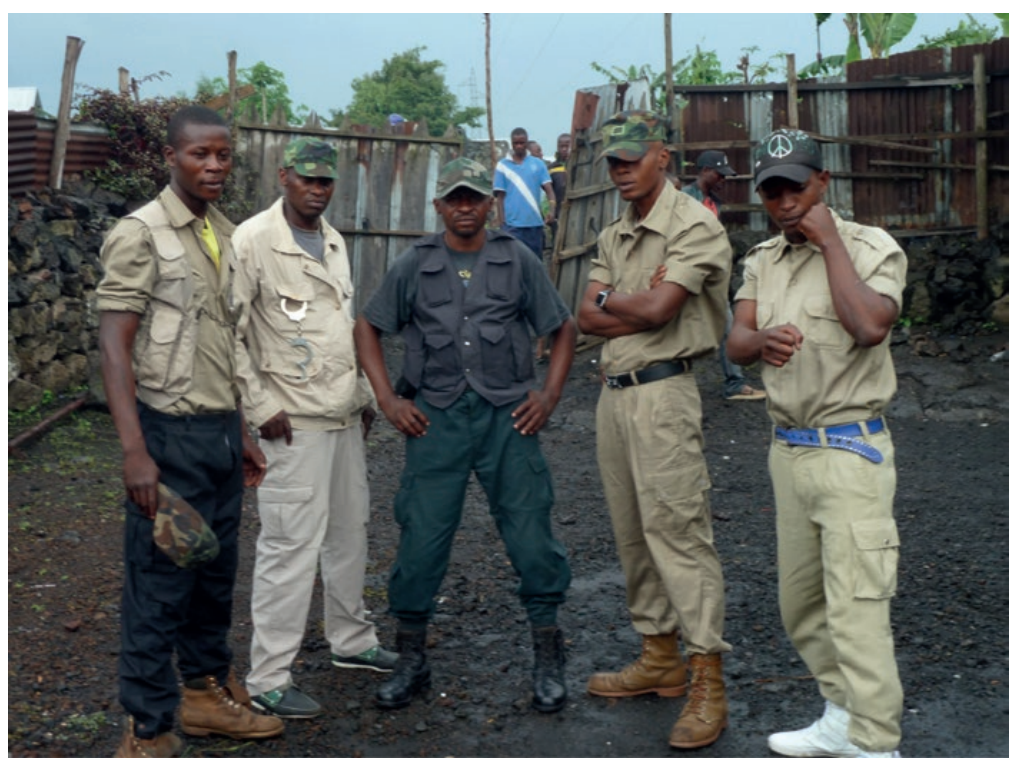

Figure 1. Maître Robin and some of his anti-gang 'elements' (Hendriks T. 2016).

one anti-gang element put it, their maitre is 'the spiritual father of both the maibobo and the anti-gangs'. ${ }^{27}$

At first sight, it seems paradoxical that a leader of those who claim to protect Goma's inhabitants against the crime and violence of maibobo also considers himself a father figure to the latter. However, on many occasions I observed how respectfully the maibobo treated anti-gang maîtres and how these maîtres at times sat down with them, sharing a plastic bag of chief (strong liquor) and cigarettes whilst chitchatting. An anti-gang maitre explained this to me as follows, using paternal metaphors:

They [the maibobo] are also children of Goma. Even in the bible, it is written that you can hit your child, to put him on the right path again. My relationship with the shege [Lingala for maibobo J is like one between father and child. It is not a question of being each other's enemies, it is a parental relationship [relation parentale]. I know all of them. We are all children of Goma [see the former section]. He who has strength corrects the other. In addition, we are supported by the state. So, we use the strength of the state and our physical force. It is not just about beating them. We do not want to kill them. It is about showing them the right path. The anti-gang are my children, but the bashege (Lingala for street children) are my children as well. ${ }^{28}$

So, through the lens of the imaginary of the father, the anti-gang is not so much about eradicating or doing away with the phenomenon of the maibobo. Rather, it is about 'transforming the maibobo into responsible citizens that do not cause trouble', ${ }^{29}$ showing them the difference between good and bad. They punish them like a father

${ }^{27}$ Informal conversation with anti-gang, Goma, 22 March 2016.

${ }^{28}$ Informal conversation with anti-gang leader, Goma, 5 November 2015.

${ }^{29}$ Informal conversation with anti-gang leader, Goma, 30 March 2016. 
punishes a bad child, which is legitimised by the bible itself. ${ }^{30}$ One way of showing these 'children' the right path is to recruit them. To be an anti-gang, after all, one must first be a gang. Many of the gangs recruited by the anti-gang have also been maibobo. By becoming an anti-gang, they can be recuperated and redeemed; work 'for the good of the population' (pour le bien de la population).

One afternoon on 11 December 2015, I witnessed a maibobo being recruited. An anti-gang called to say that they had caught a thief red-handed trying to steal phone credits. They [seven anti-gangs] were holding him at a football stadium in Goma. When I arrived, I noticed the thief was limping and could barely stand on his feet. Sitting on the tribunes of the stadium, with the thief in between us on the ground, we waited for their maître to arrive. When he did, the interrogation started. The apprehended thief begged for mercy and stressed that he was a sportif (martial arts practitioner) as well, that he had learned judo in Kinshasa. This made the anti-gang conclude that he was probably a kuluna member (youth gangs in Kinshasa that rob people with machetes), in other words a criminal. The thief now begged the anti-gang maitre to recruit him, arguing he could be of use to them. The latter decided to verify whether he was a sportif or not and ordered maitre Patient,,$^{31}$ the chef d'axe of an anti-gang group in the neighbourhood of Katindo, a black belt in Shotokan, to fight him. Already beaten up, the thief was no match for Patient, who brutally floored him thrice. Nonetheless he did prove that he mastered some judoka techniques. This convinced the anti-gang maittre to recruit him rather than handing him over to the police. ${ }^{32}$ Later that day he told me: 'I recruited him because this is our mission; make the maibobo leave the streets to become responsible men'. ${ }^{33}$

You see, all anti-gangs here are former gangs. But now they are encadrés [guided, supervised, taken care of]. Now they work for the good of the people, and they are stronger than the other gangs. ${ }^{34}$

In the anti-gang we have formed them, washed their brains, showed them the difference between good and bad. Is this wrong? ${ }^{35}$

The maitre is also a father figure to his anti-gang group to whom he refers as his 'disciples' in biblical terms. He shows them the way, protects them and 'opens their minds ${ }^{36}$ to how to make a living on the streets. He teaches low-ranked members how

\footnotetext{
${ }^{30}$ As Schatzberg notes, the political imagination of the father is permeated by religious and spiritual metaphors (Schatzberg 2001: 51).

${ }^{31}$ Since he later died, shot by a police bullet, and had explicitly asked to use his real name, the name of maître Patient is not anonymised.

32 Observation, Goma, 11 December 2015.

${ }^{33}$ Informal conversation with anti-gang coordinator, 11 December 2015.

${ }^{34}$ Informal conversation with anti-gang leader (Sarkozy), Goma, 8 December 2015.

${ }^{35}$ Informal conversation with anti-gang leader, Goma, 21 January 2016.

${ }^{36}$ Informal conversation with gang leader, Goma, 13 March 2017.
} 
to do the job of an anti-gang: coaching them in the martial arts, showing them how, where and when to do 'collections' (levy 'taxes'); and how to deal with maibobo and thieves. Moreover, a good maitre knows how to secure access to state patronage networks around the PNC, ANR and FARDC officials, and the municipal authorities. Similar to the argument of Hoffmann \& Verweijen (2019) concerning Mai-Mai rebels in the Kivus, to operate effectively, anti-gang leaders in turn need 'fatherly' protection (patronage) from state officials (see also Hendriks M. 2018). In short, as Pype (2007) writes on similar groups of sportifs in Kinshasa, they are 'at once patron and client' (Pype 2007: 259). As is common to patron-client relationships, in return for their 'gift' of protection and guidance (encadrement) in how to be an anti-gang, maitres demand loyalty and a lion's share of the group income.

When conflicts in the group arise, the maitre is the one that mediates and places a final verdict, sometimes temporarily or indefinitely suspending or physically punishing anti-gang members for going too far (for example, in the case of theft). However, his role as conflict mediator goes beyond the work sphere of being an anti-gang. In November 2015 for example, the girlfriend of an anti-gang member in the neighbourhood of Ndosho came to see the maittre of the group with a bruised eye. She accused her boyfriend of hitting her, and not making love to her anymore. The coordinator gathered a meeting and assembled all ten anti-gang members of Ndosho in a shop, where he patiently listened to both sides of the story. Afterwards, in front of everyone, he urged the anti-gang member in question to stop hitting his girlfriend. He told him that if he respected her and treats her right (also in the bedroom), she would return him the favour. ${ }^{37}$

In sum, the maitre is a leader and father figure who provides guidance to the rest of the anti-gang group. Economically, by providing them with an income through the weekly 'collections' and other small jobs. Politically, by securing protection ${ }^{38}$ and the patronage of officials and politicians. In terms of physical condition and fitness, by coaching them in the martial arts. And finally, morally, for example by intervening in family disputes and teaching them 'the difference between good and bad'.

To come back to Schatzberg's (2001) analyses, the above is a clear example of how the political imagination of the father, of government relating to citizens as a father to his children, is replicated throughout society. Just as the president is seen as the father of the nation, anti-gang leaders consider themselves as father figures to maibobowho need to be educated, corrected and shown the right path - and to anti-gangs, of whom he takes care. In this way, the political imagination of the father informs how anti-gangs see themselves in (hierarchical) relation to each other, and the maibobo and thieves they have sworn to police. It gives shape to the anti-gang's social cause:

37 Observation, 20 November 2015, Ndosho.

${ }^{38}$ For example, by using their influence to keep them out of prison when in conflict with other authorities. 
to transform the maibobo into responsible men, teaching them the difference between right and wrong. Moreover, it also shapes the role and responsibilities of patronage and 'care' of anti-gang leaders. By acting upon this political imagination and adapting it to their lifeworld, they contribute, in their way, to giving shape to this prevalent imaginary foundation of authority on which Congo's political order is built.

\section{Martial arts and action movies}

A fourth form of political imagination that inspires anti-gang politics of everyday policing is drawn from the popular imagery of martial arts and action movies. This is not specific to either anti-gangs or Goma or Congo. Fighters such as Bruce Lee, JeanClaude Van Damme and Sylvester Stallone serve as role models for many young men across Africa and elsewhere (Richards 1996; Jourdan 2004; Bazenguissa-Ganga 1999; Hoffmann 2010; Joseph 1999; van Staden 2017; High 2010; Pype 2007).

The anti-gang's very foundation was inspired by martial arts- and action movies. In 2007, disturbed by the aggravated harassments of the Virunga market by maibobo (pickpocketing and extorting from traders and their customers), Maittre Robin, a judo master and money exchanger at the market, told the president of the market committee: 'In the USA, there is a group of anti-gang, led by Jean-Claude Van Damme who fights gangsters, they are sportifs, we can do the same thing here'. ${ }^{39}$ The latter agreed, and the anti-gang, coordinated by Maitre Robin, came into being. This section elaborates on how the global imagery of martial arts and action movies serves as an 'imaginary space' (Pype 2007; Gondola 2016) that shapes and is also shaped by anti-gang - and gang - practices, giving form to hypermasculine imaginations around order-making in the process.

In Tropical Cowboys, Didier Gondola (2016) eloquently describes how in their quest for masculinity, ${ }^{40}$ in Leopoldville ${ }^{41}$ of the 1950 s, youth gangs fashioned themselves through the imagery of the Western, which resulted in the so-called Bill movement, and later the Yankees. Across Africa, the Hollywood Western was one of the first popular film genres introduced to colonised audiences. This was no accident. In the colonial imaginary, the white hero gunslinger taming the 'Wild West' and its 'natives' bared resemblance and to some extent legitimated (in their eyes) the

${ }^{39}$ Informal conversation with Maitre John, Goma, 1 February 2016.

${ }^{40}$ An in-depth elaboration of the different discourses of (subaltern) masculinities in Congo is beyond the scope of this article. For a much more coherent overview of the contemporary debates on masculinities in Congo - next to the authors referred to in this article - the work of Thomas Hendriks (2016; 2019; 2021; forthcoming) and Jeroen Cuvelier (2014; 2017) is a must read.

${ }^{41}$ Leopoldville was the name for Kinshasa in the colonial period. 
European's colonising work on the African frontier. Soon, however, anxieties arose on the part of the colonial administration about the bad influence of Westerns on youth, after the imagery of the Western started to shape youth and gang culture (van Staden 2017; Ambler 2001; Suriano 2008; Nixon 1994). On Leopoldville, Gondola states:

Young people, especially, parlayed their vision of the Far West from the screens into the street, creating in the process a unique hybrid blend that conflated the Hollywood version of the drifting cowboy with local elements of manhood and fashioned township gangs after frontier possess (Gondola 2016: 66).

As Pype (2007: 264) asserts on Kinshasa: 'the consumption of Westerns in movie theatres ... propagated the cowboy as a new ideal of masculinity'. It provided youth with an 'imaginary space' to draw models, styles and behaviours from: models such as Buffalo Bill and Billy the Kid; styles of walking, talking and dress such as the cowboy hat and boots; and moral and behavioural codes, for example of when and how to engage in a fight (Gondola 2016; Pype 2007). They did not just mimic the Western imagery, but 'appropriated and reinterpreted film images in their own terms' (Ambler 2001: 87), performing 'their own tropical version of Hollywood's Far West' (Gondola 2016: 72).

Before reading any further, I suggest you scan the QR code on the left, or open the link in the footnote, ${ }^{42}$ to take a look to a fiction film that TD Jack, a Goma-based cineaste, and I co-produced together with an anti-gang group in the neighbourhood of Ndosho. In this film, which came into being on their demand, they re-enacted their lifeworld and experiences as gangs and anti-gangs the way they saw fit. ${ }^{43}$ In sum, they came up with the idea for the script, acted, and gave us feedback during the editing process. TD Jack and I aimed to facilitate as well as possible the making of their film (see Hendriks M. 2019). Better than I could ever write, the film shows how gangs and anti-gangs today-in similar fashion to the Bills through the Western genre in the 1950 s - style their political subjectivity in relation to martial arts and action movies.

The film, based on true events, tells the story of Monstre ending up in and escaping from prison, using no more than grinded chilli peppers. Interestingly, the film starts and ends with re-enactments of scenes of the action movie Expendables II, starring an impressive cast of fighters with actors such as Sylvester Stallone, Jean-Claude Van Damme, Jet Li, Terry Crews, Chuck Norris, Arnold Schwarzenegger, Bruce Willis and Jason Statham. In this movie, the mercenary group the Expendables led by Ross (Sylvester Stallone) is engaged by a CIA agent (Bruce Willis) to retrieve a blueprint of a plutonium mine from a crashed plane wreck in Albania. After having retrieved the item, the Expendables are ambushed by the criminal mastermind Villain (JeanClaude Van Damme) and his mercenary group the Sangs, who want the blueprint for

42 www.youtube.com/watch?v=rnuJQGa6bEI

${ }^{43}$ Similar to the principles behind the making of Jean Rouch's film Moi, un Noir (1958). 
themselves in order to mine the plutonium and sell it to the highest bidder. They take the plutonium and kill Billy, the youngest of the Expendables. Ross swears revenge and at the end of the movie [spoiler alert] kills Villain in an epic hand-to-hand fight.

In short, the anti-gang's own action movie dramatises the true events of Monstre ending up in - and escaping from - prison through scenes of the Expendables II, modelling the anti-gang leader on the image of Sylvester Stallone. Monstre's version starts at the mine of Kalimbi, Nyabibwe ${ }^{44}$ - around 120 kilometres south of Goma. This is where, before ending up with the anti-gang in Goma, Monstre led a group of barasta that 'provided security' on one of the hills in the mine. Instead of recovering an Albanian plutonium mine blueprint, he and his crew retrieve a diamond under a big rock. As in Expendables II, Monstre's group is being ambushed by the group of John Cena (the leader of the anti-gang group, imitating Jean-Claude Van Damme). After they kill one of Monstre's men in the same way as Billy in the Expendables, Monstre is taken to prison. Here, the re-enactment of Monstre's own story escaping from prison starts. The action movie illuminates what gangs and anti-gangs mean by expressing: 'my life is like a [action] movie', or 'I have lived a lot of movies'. Elaborating on the real conditions by which Monstre was sent to prison, he stated:

They caught me at the lake. We already passed a lot of rivers, there were a lot of gunshots. I had to do a lot of jumps. It was like in a movie. ... I was in trouble at the lake, because I did not know how to swim. ... I hid myself in a hole under a tree at the river.... I had a shot wound in my hand, in between two fingers. ${ }^{45}$

During my fieldwork, anti-gangs often dramatised events - such as fights with other gangs, conflicts with the police and fellow gang members - through the scenes of martial arts and action movies. For example, one day an anti-gang leader told how he suspected one of the members of collaborating with thieves. To explain how he felt, he referred to a movie he saw on the Cold War, in which a commander of a group of American soldiers confronted a traitor and shot him. Disillusioned with the fact that he could not trust his own men, the anti-gang leader argued that he now found himself in a similar situation. ${ }^{46}$

Gangs and anti-gangs do not only imagine themselves living movies, but also appropriate, reinterpret and put into action terms, styles and behaviours from this movie imagery (see Pype 2007; Ambler 2001). Up until today - as one can see in Monstre's action film - gangs in Goma still refer to themselves as cowboys and yankees, a vocabulary clearly appropriated from the Western genre (Bazenguissa-Ganga 1999). Similar to the use of the word gang, the words cowboy and yankee denote toughness in both a positive and negative sense. Whilst used to refer to marginalised

\footnotetext{
44 The entire film was shot in Goma.

${ }^{45}$ Interview with Monstre, Goma, 2 July 2017.

${ }^{46}$ Informal conversation with anti-gang leader, Goma, 21 February 2017.
} 

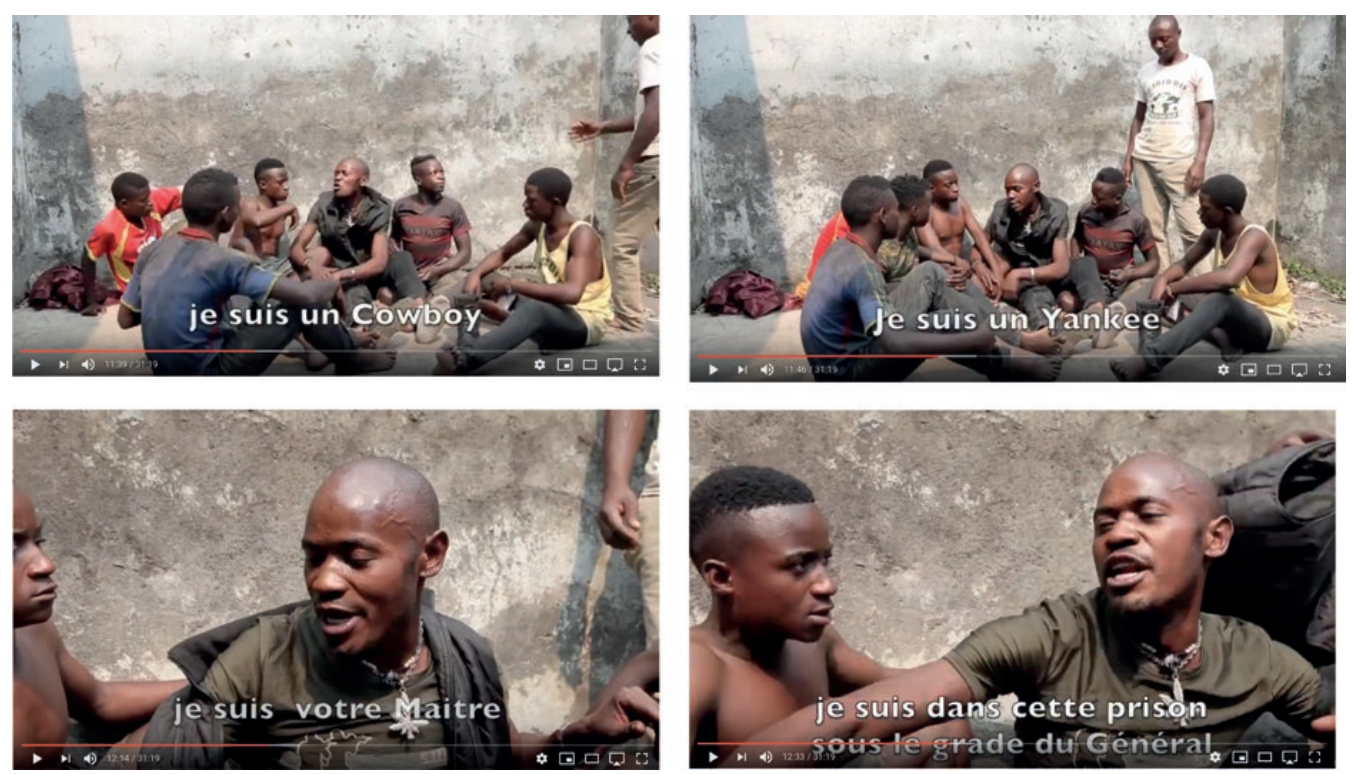

Figure 2. Screenshots from the fiction film on Monstre's prison break we made together with an antigang group.

youths and voyous (bandits) of the neighbourhood, it also designates 'anyone who does not fear risk' (Pype 2007: 265-6) and 'l'homme fort par excellence' [the ultimate strong man] (Bazenguissa-Ganga 1999: 340). In the anti-gang's action movie, Monstre is harassed by his fellow inmates once he arrives in his prison cell (a common practice in Congolese prisons). To make them stop, he convinces his fellow prisoners - to whom he refers as his petits (little ones, inferiors) - that he is a real yankee, a cowboy and a maitre (a patron amongst gangs) with the grade of general (another example of gangs and anti-gangs enacting languages of stateness) who is going to make them escape.

Through the imagery of martial arts and action movies, gangs and anti-gangs shape their identity as sportifs. Whilst not all sportifs in Goma are gangs, being a good sportif is highly valued in this gang world (Hendriks M. 2019). It is best to be trained in more than one discipline of the martial arts, in order to not get outwitted in a street fight when being confronted with sportifs trained in disciplines with which one is not acquainted. Through martial arts, so they argue, the anti-gang transform their bodies into a weapon. ${ }^{47}$ It provides them with strength, muscled bodies and social status on the streets (Pype 2007). Fighting techniques and styles are often directly appropriated out of martial arts and action movies. For example, one anti-gang leader started to teach his pupils Thai boxing after he saw the movie Ong Back: The Thai Warrior

${ }^{47}$ Informal conversation with anti-gang leader, Goma, 5 November 2015. 
(2003), a style, he argued, that was yet unknown in Congo. ${ }^{48}$ On the job, anti-gangs carry self-fabricated iron nunchuks, which, in addition to being a fierce weapon, are also a key symbol drawn from the imagery of martial arts movies, through which they underline and materialise their identity as $\operatorname{sportifs} ;{ }^{49}$ the $\mathrm{QR}$ code on the right shows a sportif doing a nunchuk performance.

Similar to what Gondola (2016) argues concerning the Bills in the 1950s, sportifs in Goma also draw a moral and 'behavioural lexicon' from martial arts and action movies. As martial arts transform one's body into a weapon, one should be careful how and against whom to use it. Much like the frugal Bruce Lee who never provokes a fight and only takes on villains, the anti-gang assert that 'in front of people that do not do sports [martial arts] you need to be humble'. ${ }^{50}$ 'Hitting thieves and maibobo is okay. You are in your right. But you can't use your nunchuk against everyone. It is a mordacious weapon. ${ }^{51}$ 'We do not want controversies. I know that I am stronger, but I do not smack everyone in the face. If I hit them with this arm [points to his right arm], blood will flow. If then I end up in prison, I need to start all over again [once released]. ${ }^{95}$

Moreover, much like their model fighters in martial arts and action movies, as one gang leader explained, 'a real maitre is calm and has self-control, even when he is drunk .... A good maître has mastery over himself and knows how to master others. He will not fight with just anyone or be the first to hit someone'. ${ }^{53}$ Also in the antigang's action movie Monstre, by presenting himself as a maitre, the protagonist shows in his attitude that he masters himself-literally working on his body - and is firmly in control of his environment and the people in it. He takes the lead over other prisoners, calmly working out an escape strategy, whilst not being intimidated by the prosecutor in charge of his case nor the guards. In sum, although gangs in Goma and elsewhere in Congo (see Wilson 2012; Geenen 2009; Hendriks T. 2019; Hendriks M. et al. 2013; Hollington \& Nassenstein 2017) still refer to themselves as yankees and cowboys, the imaginary space through which gangs fashion their subjectivity has made room for the imagery of martial arts and action movies.

Van Staden argues that the rise in popularity of Asian martial arts movies amongst African audiences since the 1970s, after the success of the Western genre, is attributed to its 'changed racial dynamics and explicit anti-colonial imagery' (van Staden 2017: 11). The 1970s represent a time where many African countries recently gained or were still struggling for independence. In Bruce Lee's international breakthrough Enter the

${ }^{48}$ Informal conversation with anti-gang leader, Goma, 22 March 2017.

${ }^{49}$ https://www.youtube.com/watch?v=TEDwlgToiJY

${ }^{50}$ Informal conversation with anti-gang leader, Goma, 17 February 2017.

${ }^{51}$ Informal conversation with anti-gang, Goma, 15 May 2017.

52 Informal conversation with anti-gang leader, Goma, 17 February 2017.

${ }^{53}$ Informal conversation with gang leader, Goma, 6 March 2017. 
Dragon (1973) for example, white guys are beaten by Asian and even African American fighters, who explicitly brought in the theme and imagery of the black American struggle (ibid.). ${ }^{54}$ According to May Joseph (1999), another appeal of Bruce Lee's movies to Tanzanian audiences is that his films are embedded in an 'aesthetics of frugality' which resonates with the frugality of everyday life for most young Tanzanians (Joseph 1999: 51-5). Lee mostly plays a very modest character-such as a factory worker, peasant or country bumpkin - for whom little is enough and self-discipline is everything. $\mathrm{He}$ does not walk around with guns and bombs. His only weapon - of frugality-is his body trained in the martial arts. Although the American martial arts genre is to a large extent an appropriation of its Asian counterpart, it is hard to defend the argument that its appeal to African audiences still lies in its anti-colonial imagery or aesthetics of frugality (see van Staden 2017: 14). American martial arts and action movies bring back in the trope of the good, brave, white American hero fighting evils such as communism, criminals and dictators, often by shooting and blowing up everything and everyone that stands in their way.

What binds Billy the Kid, Bruce Lee, Jean-Claude Van Damme, Sylvester Stallone and Arnold Schwarzenegger together is that they are tough hypermasculine 'problem solvers' (Joseph 1999) in a world full of danger. They are all 'subject to grave injustices and are made to suffer immensely before they vanquish their enemies against all odds through the use of spectacular violence' (Hoffmann 2010: 354). Westerns and Asian and American martial arts movies have in common that they are celebrations of male bravado. As Pype (2007: 264) notes: 'These media products show virile men, who are self-confident, in control of everything, energetic and dynamic. They control their health and are able to confront any physical danger; in a word, they are invincible'. Similar to Hoffmann's (2010) argument concerning Mai-Mai rebels in South Kivu (DR Congo), gangs and anti-gangs in Goma identify with the ethos of these films since they see their condition as very familiar. Kigang life in the Kivus is full of danger, injustice and suffering. Fighters of the likes of Bruce Lee, Jean-Claude Van Damme and Sylvester Stallone serve as role models for how to deal with structural and everyday violence that surrounds them. Additionally, in the case of the anti-gang, they are models for how to restore order in a troubled city (see Joseph 1999: 57). Writing on Waorani men, an indigenous group in Ecuador of which previous generations were known as fierce hunters and warriors, High (2010: 762) asserts that 'images of Bruce Lee and Rambo appear to embody a fantasy of masculine power and generational continuity that young men idealize, even if they fail to demonstrate it in everyday life'. The action film on Monstre's prison break however shows that global imagery of martial arts and action movies is more than a masculine fantasy. They live these movies.

${ }^{54}$ The black struggle is embodied in the actor Jim Kelly, who fights racist policemen and trains his fellow African Americans in his own karate club decorated with black power symbols (van Staden 2017). 
Similar to what Pype notes for sportifs in Kinshasa: 'They inhabit and act out the virility of the mass-mediated fictive figures. In this way, the masculinity of the young fighting Kinois is 'more real' than the images they imitate' (Pype 2007: 267).

To summarise, anti-gang practices and everyday politics are infused by the global imagery of Asian and American martial arts and action movies. Political imaginations related to these movies shape how social status is acquired on the streets, how sportifs and gangs style their identity, and set up moral and behavioural codes. Moreover, they provide marginalised urban youths with role models to look up to in order to fight back against injustice and the violence that surrounds them. At the same time, by living these movies, anti-gang members also give form to a 'tropical version' (Gondola 2016: 72) of the hypermasculine political imaginations present in this global movie imagery.

\section{Conclusion}

In this article, I examined the role of the imagination in how the anti-gang in Goma impose themselves as street authorities. I demonstrated that far from being figments of the mind, political imaginations around the state, citizenship, the father, and martial arts and action movies are harnessed by the anti-gang to do political work. They shape how anti-gangs legitimise themselves, see themselves in relation to the maibobo and state agents, acquire social status, style their political subjectivity, engage in political actions of order-making and policing (such as evicting pirate markets and catching thieves), understand the anti-gang's social cause (transforming the maibobo in responsible men), what they expect from their leaders and what it takes to be one. Furthermore, the work of the imagination is involved in how the anti-gang adhere to forms of political belonging, hierarchy, and moral and behavioural codes.

By enacting them through various performances - such as by wearing uniforms, waving their nunchuks, recruiting maibobo, and acting 'state-like'-anti-gang practices in turn materialise and give form to political imaginations of order-making and authority in the concrete socio-political policing environment and everyday urban life of Goma. In other words, by drawing from and conferring meaning to political imaginations around the state, citizenship, the father, and martial arts and action movies, the anti-gang contribute to making them matter and experienced as real.

The anti-gang's struggle to impose themselves as street authorities in Goma's popular neighbourhoods is indeed, to some extent, as Mbembe argues, aimed at 'establishing new forms of legitimate domination and gradually restructuring formulas of authority built on other foundations' (Mbembe 2001: 76). At the same time, through the analyses of the imaginary foundations that underlie the anti-gang's street authority, it is also clear that the anti-gang do not so much envision a new political order. 
Instead, they seek to be included in it and become politically significant. As Helene Kyed argues on street authority, it 'does not fundamentally overturn prevailing relations of power and political systems .... However, it does provide an implicit political critique of the prevailing state of affairs ...' (Kyed 2018: 32).

The anti-gang impose themselves as street authorities, feeding into and informed by prevalent political imaginations of authority and order-making: the state as organising principle of society; auto-prise en charge and being Gomatracien; the father taking care of and disciplining his children; and hypermasculine political imaginations inspired by martial arts and action movies centred around the courageous action hero, mastering himself and others and bringing order to a treacherous world.

As Sneath et al. (2009) note on the literature on social imaginaries, there is often a tendency to romanticise the emancipatory and progressive potential of the imagination to ultimately lead to a better world. However, as Jaffe illustrates concerning the role of the political imagination in urban rule by criminal leaders (so-called 'dons') in Kingston, we should also be prepared to meet 'the more dystopian potentials of imaginative engagement' which relate to violent political practices (Sneath et al. 2009, cited in Jaffe 2018: 1100). The way in which the anti-gang imagine themselves as street authorities is also in many ways a violent enterprise. It does certainly not envision a fundamentally brighter or better future. At the same time, however, their imaginative and 'real' endeavours of imposing themselves as street authorities should be read first and foremost as an attempt by marginalised youths to escape their exclusion from social, political and economic life, and to make themselves matter.

\section{Acknowledgements}

I would like to thank my research collaborators TD Jack Muhindo, Christian Irenge Bunguke and Rosette Watanga for their crucial role in bringing this research project and publication to a good end. I also want to thank Karen Büscher, Kasper Hoffmann and Koen Vlassenroot for their support and engagement with my work.

\section{References}

Ambler, C. (2001), 'Popular Films and Colonial Audiences: The Movies in Northern Rhodesia', The American Historical Review, 106(1): 81-105. https://doi.org/10.2307/2652225

Bazenguissa-Ganga, R. (1999), 'Les Ninja, les Cobra et les Zoulou Crèvent l'écran à Brazzaville: Le Rôle les Médias et la Construction des Identités de Violence Politique', Canadian Journal of African Studies / Revue Canadienne Des Études Africaines, 33(2-3): 329-61. https://doi.org/10.1080/0008 3968.1999.10751165

Beall, J., Goodfellow, T. \& Rodgers, D. (2013), 'Cities and Conflict in Fragile States in the Developing World', Urban Studies, 50(15): 3065-83. https://www.jstor.org/stable/26145646 
Büscher, K. (2011), 'Conflict, State Failure and Urban Transformation in the Eastern Congolese Periphery', PhD thesis (Ghent University). https://biblio.ugent.be/publication/2092391/ file/4335807

Büscher, K. (2016), 'Reading Urban Landscapes of War and Peace: The Case of Goma, DRC', in A. Björkdahl \& S. Buckley-Zistel (eds) Spatializing Peace and Conflict: Mapping the Production of Places, Sites and Scales of Violence (London, Palgrave Macmillan), 79-97. http://hdl.handle. net/1854/LU-7187709

Büscher, K. (2018), 'African Cities and Violent Conflict: The Urban Dimension of Conflict and Post Conflict Dynamics in Central and Eastern Africa', Journal of Eastern African Studies, 12(2): 193 210. https://doi.org/10.1080/17531055.2018.1458399

Büscher, K. \& Vlassenroot, K. (2010), 'Humanitarian Presence and Urban Development: New Opportunities and Contrasts in Goma, DRC', Disasters, 34(S2): S256-73.

Carayannis, T., Vlassenroot, K., Hoffmann, K. \& Pangburn, A. (2018), 'Competing Networks and Political Order in the Democratic Republic of Congo: A Literature Review on the Logics of Public Authority and International Intervention'. Conflict Research Program, London School of Economics. http://hdl.handle.net/1854/LU-8593899

Cuvelier, J. (2014), 'Work and Masculinity in Katanga's Artisanal Mines', Africa Spectrum, 49(2): 3-26. https://journals.sub.uni-hamburg.de/giga/afsp/article/view/752

Cuvelier, J. (2017), 'Money, Migration and Masculinity among Artisanal Miners in Katanga (DR Congo)', Review of African Political Economy, 44(152): 204-19. https://doi.org/10.1080/030562 44.2016.1172061

Feltran, G. (2020), The Entangled City: Crime as Urban Fabric in São Paulo (Manchester, Manchester University Press).

Geenen, K. (2009), “Sleep Occupies No Space”: The Use of Public Space by Street Gangs in Kinshasa', Africa, 79(3): 347-68. https://doi.org/10.3366/E0001972009000850

Goldstein, D.M. (2012), Outlawed: Between Security and Rights in a Bolivian City (Durham NC, Duke University Press).

Gondola, Ch D. (2016), Tropical Cowboys: Westerns, Violence, and Masculinity in Kinshasa (Bloomington IN, Indiana University Press).

Gore, C. \& Pratten, D. (2003), 'The Politics of Plunder: The Rhetorics of Order and Disorder in Southern Nigeria', African Affairs, 102(407): 211-40. http://www.jstor.org/stable/3518677

Grätz, T. (2010), 'Dévi \& His Men: The Rise \& Fall of a Vigilante Movement in Benin', in T. Grätz \& T.G. Kirsch (eds), Domesticating Vigilantism in Africa (New York, James Currey), 79-97.

Hansen, T.B. \& Stepputat, F. (2001), States of Imagination: Ethnographic Explorations of the Postcolonial State, 1st edn (Durham NC, Duke University Press).

Harnischfeger, J. (2010), 'Ethnicity, Religion \& the Failure of “Common Law” in Nigeria', in T.G. Kirsch \& T. Grätz (eds), Domesticating Vigilantism in Africa (Woodbridge, Boydell \& Brewer), 51-78.

Hendriks, M. (2018), 'The Politics of Everyday Policing in Goma: The Case of the Anti-Gang', Journal of Eastern African Studies, 12(2): 274-89. https://doi.org/10.1080/17531055.2018.1459976

Hendriks, M. (2019), “My Life Is Like a Movie”: Making a Fiction Film as a Route to Knowledge Production on Gang Political Performances in Goma, DR Congo', Journal of Extreme Anthropology, 3(1): 57-76. https://doi.org/10.5617/jea.6695

Hendriks, M. \& Büscher, K. (2019), Insecurity in Goma: Experiences, Actors and Responses (London and Nairobi, Usalama Project, Rift Valley Institute).

Hendriks, M., Ponsaers, P. \& Shomba Kinyamba, S. (2013), 'Street Children in Kinshasa. Striking a Balance between Perpetrator and Victim through Agency', Etnografia e Ricerca Qualitativa, 1. https://doi.org/10.3240/73068

Hendriks, T. (2016), 'SIM Cards of Desire: Sexual Versatility and the Male Homoerotic Economy in Urban Congo', American Ethnologist, 43(2): 230-42. https://doi.org/10.1111/amet.12301

Hendriks, T. (2019), 'Queer(Ing) Popular Culture: Homo-Erotic Provocations from Kinshasa', Journal of African Cultural Studies, 31(1): 71-88. https://doi.org/10.1080/13696815.2017.1341833 
Hendriks, T. (2021), “"Making Men Fall”: Queer Power beyond Anti-Normativity', Africa, 91(3): 398417. https://doi.org/10.1017/S000197202100022X

Hendriks, T. (forthcoming), Rainforest Capitalism: Power and Masculinity in a Congolese Timber Concession (Durham NC, Duke University Press).

High, C. (2010), 'Warriors, Hunters, and Bruce Lee: Gendered Agency and the Transformation of Amazonian Masculinity', American Ethnologist, 37(4): 753-70. https://doi. org/10.1111/j.1548-1425.2010.01283.x

Hoffmann, K. (2010), 'The Ethics of Child-Soldiering in the Congo', YOUNG, 18(3): 339-58. https:// doi.org/10.1177/110330881001800306

Hoffmann, K. \& Verweijen, J. (2019), 'Rebel Rule: A Governmentality Perspective', African Affairs, 118(471): 352-74. https://doi.org/10.1093/afraf/ady039

Hoffmann, K., Vlassenroot, K. \& Marchais, G. (2016), 'Taxation, Stateness and Armed Groups: Public Authority and Resource Extraction in Eastern Congo', Development and Change, 47(6): 1434-56. https://doi.org/10.1111/dech.12275

Hollington, A. \& Nassenstein, N. (2017), 'From the Hood to Public Discourse: The Social Spread of African Youth Languages', Anthropological Linguistics, 59(4): 390-413. https://doi. org/10.2307/26559036

Jaffe, R. (2018), 'Cities and the Political Imagination', The Sociological Review, 66(6): 1097-110. https:// doi.org/10.1177/0038026118769832

Joseph, M. (1999), 'Kung Fu Cinema, Frugality and Tanzanian Asian Youth Culture: Ujamaa and Tanzanian Youth in the Seventies', in M. Randy \& T. Miller (eds), SportCult (Minneapolis MN: University of Minnesota Press), 41-63.

Jourdan, L. (2004), 'Being at War, Being Young: Violence and Youth in North Kivu', in K. Vlassenroot \& T. Raeymaekers (eds), Conflict and Social Transformation in Eastern DR Congo (Ghent, Academia Press Scientific Publishers) 157-176.

Kirsch, T.G. \& Grätz, T. (eds) (2010a), Domesticating Vigilantism in Africa (New York, James Currey).

Kirsch, T.G. \& Grätz, T. (2010b), 'Vigilantism, State Ontologies \& Encompassment: An Introductory Essay', in Kirsch \& Grätz (2010a).

Kyed, H.M. (2015), 'Rival Forms of Policing and Politics in Urban Swaziland', in Albrecht \& Kyed (2015), 57-73.

Kyed, H.M. (2018), 'Street Authorities: Community Policing in Mozambique and Swaziland', PoLAR: Political and Legal Anthropology Review, 41(S1): 19-34. https://doi.org/10.1111/plar.12251

Kyed, H.M. \& Albrecht, P. (2015), 'Introduction: Policing and the Politics of Order-Making on the Urban Margins', in P. Albrecht \& H.M. Kyed, (eds), Policing and the Politics of Order-Making (New York, Routledge), 169-86.

Lund, C. (2006), 'Twilight Institutions: Public Authority and Local Politics in Africa', Development and Change, 37(4): 685-705.

Mbembe, A. (2001), On the Postcolony (Berkeley and Los Angeles CA, University of California Press. https://www.ucpress.edu/book/9780520204355/on-the-postcolony

Mbembe, A. (2002), 'African Modes of Self-Writing', translated by S. Rendall, Public Culture, 14(1): 239-73. https://muse.jhu.edu/article/26273

Meyer, B. (2009a), Aesthetic Formations: Media, Religion, and the Senses (New York, Palgrave Macmillan). https://doi.org/10.1057/9780230623248

Meyer, B. (2009b), 'Introduction: From Imagined Communities to Aesthetic Formations: Religious Mediations, Sensational Forms, and Styles of Binding', in B. Meyer (ed.), Aesthetic Formations: Media, Religion, and the Senses (New York, Palgrave Macmillan) 1-28. https://doi. org/10.1057/9780230623248_1

Mitchell, T. (1991), 'The Limits of the State: Beyond Statist Approaches and Their Critics', The American Political Science Review, 85(1): 77-96. 
Mitton, K. (2018), 'War by Another Name? The “Urban Turn” in 21st Century Violence', T. Note Human Security, 59(7).

Muzalia, G. (forthcoming), Insécurité dans la ville de Bukavu au Sud-Kivu: Perspectives historiques (1960-2018). (Bukavu, Groupe d'Etudes sur les Conflits et la Sécurité Humaine).

Nixon, R. (1994), Homelands, Harlem and Hollywood: South African Culture and the World Beyond, 1st edn (New York, Routledge).

Pole Institute. (2009), Est de la RDC: Le Crime Banalisé (No. 23), Regards Croisés. (Goma, Pole Institute).

Pratten, D. \& Sen, A. (eds.) (2007), Global Vigilantes, new edn (London, C Hurst \& Co Publishers Ltd.).

Pype, K. (2007), 'Fighting Boys, Strong Men and Gorillas: Notes on the Imagination of Masculinities in Kinshasa', Africa, 77(2): 250-71. https://doi.org/10.3366/afr.2007.77.2.250

Richards, P. (1996), Fighting for the Rain Forest (Portsmouth NH, Heinemann).

Rouch, J. (1958), Moi, Un Noir. Ethnofiction. Icarus Films. https://www.youtube.com/ watch? $=\mathrm{rDmHpZcXee} 0$

Sardan, J.P.O. de. (2008), 'Researching the Practical Norms of Real Governance in Africa', Africa Power \& Politics Program (London, Overseas Development Institute).

Schatzberg, M.G. (2001), Political Legitimacy in Middle Africa: Father, Family, Food (Bloomington IN, Indiana University Press).

Sneath, D., Holbraad, M. \& Pedersen, M.A. (2009), 'Technologies of the Imagination: An Introduction', Ethnos, 74(1): 5-30. https://doi.org/10.1080/00141840902751147

Suriano, M. (2008), 'Clothing and the Changing Identities of Tanganyikan Urban Youths, 1920s-1950s', Journal of African Cultural Studies, 20(1): 95-115. https://doi.org/10.1080/13696810802159321

Thill, M. (2019), 'A System of Insecurity: Understanding Urban Violence and Crime in Bukavu', Usalama III (London and Nairobi, Rift Valley Institute).

Thill, M. \& Cimanuka, A. (2019), 'La Gouvernance de la Sécurité à l'est du Congo: Décentralisation, Réforme de la Police et Interventions dans la Chefferie de Buhavu'. http://hdl.handle.net/1854/ LU-8650604

Turner, V. (1982), From Ritual to Theatre: The Human Seriousness of Play (New York, PAJ Publications). van Staden, C. (2017), 'Watching Hong Kong Martial Arts Film under Apartheid', Journal of African Cultural Studies, 29(1): 46-62. https://doi.org/10.1080/13696815.2016.1236720

Verweijen, J. (2016), 'Between "Justice" and "Injustice": Justice Populaire in the Eastern DR Congo', 4. JSRP Policy Brief Series (London, The Justice and Security Research Programme).

Verweijen, J. (2019), 'Violent Cities, Violent Society: Analyzing Urban Violence in the Eastern Congo', Usalama III (London, Rift Valley Institute).

Wilson, C. (2012), 'The Congolese Yankee: Language and Identity among Youth in Kisangani', Master's thesis (Leiden, Universiteit Leiden).

Wolf, E.R. (1999), Peasant Wars of the Twentieth Century, 1st edn (Norman OK, University of Oklahoma Press).

To cite the article: Maarten Hendriks (2021), 'Imagining the anti-gang: the state, the father and Jean-Claude Van Damme', Journal of the British Academy, 9(s11): 41-65. DOI https://doi.org/10.5871/jba/009s11.041

Journal of the British Academy (ISSN 2052-7217) is published by

The British Academy, 10-11 Carlton House Terrace, London, SW1Y 5AH

www.thebritishacademy.ac.uk 